\title{
Hannah Arendt e Ruy Fausto sobre a gênese do totalitarismo de esquerda*
}

\author{
Hannah Arendt and Ruy Fausto on the genesis of left-wing \\ totalitarianism
}

\author{
Yara Frateschi \\ yfrateschi@gmail.com \\ (Universidade Estadual de Campinas, São Paulo, Brasil)
}

\begin{abstract}
Resumo: 0 presente artigo reconstrói as análises que Hannah Arendt e Ruy Fausto fazem das origens do totalitarismo de esquerda a fim de mostrar que, embora Fausto pretenda preencher uma lacuna deixada por Arendt, o caminho que ele segue ao traçar a gênese do totalitarismo soviético é o mesmo seguido por ela nos anos 1950 e 1960 e vai do stalinismo para o leninismo, para o bolchevismo chegando ao jacobinismo, sem descuidar do importante legado de Marx e também do menos evidente legado das filosofias modernas do progresso.
\end{abstract}

Palavras-chave: Hannah Arendt; Ruy Fausto; Totalitarismo; Jacobinismo; Bolchevismo.

\begin{abstract}
This article reconstructs Hannah Arendt and Ruy Fausto's analysis of the origins of left-wing totalitarianism in order to show that, although Fausto intends to fill a gap left by Arendt, the path he follows in tracing the genesis of Soviet totalitarianism is the same followed by her in the 1950's and 1960's and goes from Stalinism to Leninism, to Bolshevism to Jacobinism, without neglecting the important legacy of Marx and also the less evident legacy of the modern philosophies of progress.
\end{abstract}

Keywords: Hannah Arendt; Ruy Fausto; Totalitarianism; Jacobinism; Bolshevism.

Este artigo surge da inquietação diante de uma característica persistente de parte não desprezível da esquerda de ontem e de hoje, no Brasil e alhures: a justificação da violência pelos motivos certos. Surge ainda da inquietação perante uma evidente incongruência entre a prontidão para censurar a violência cometida pela direita (colonial, imperialista, capitalista) e a justificar a sua própria. Os tempos passam, a situação histórica se modifica, mas uma porção da esquerda continua relativista a respeito da violência e, consequentemente, a respeito dos direitos (civis e políticos) e dos direitos humanos. Quando governos de direita os desrespeitam, são considerados antidemocráticos; quando governos de esquerda os sacrificam, o fazem por necessidade. Contra a direita, argumento de princípio; a favor da esquerda,

* Agradeço imensamente às leituras atentas e às sugestões que Nathalia Rodrigues da Costa, Nádia Junqueira Ribeiro, Renata Romolo Brito e Bruno Nadai fizeram da primeira versão desse texto. Agradeço também à Simone Fernandes pela revisão cuidadosa. 
argumento de circunstância.

No Brasil, até mesmo uma parte da esquerda que optou por entrar no jogo democrático continua a sustentar um discurso descompassado que censura algumas ditaduras, mas cultiva regimes fechados; que reivindica os direitos humanos aqui, mas convive bem com a ideia de que sejam suspensos, em outros lugares, em nome da guerra contra o imperialismo; que reclama a democratização dos meios de comunicação brasileiros, mas defende o seu controle pesado quando for pela causa da revolução. Não se trata aqui de analisar detidamente esses discursos contemporâneos, mas sim de refletir sobre a gênese do relativismo de esquerda. Ou, em outros termos, sobre a origem dessa cisão entre argumento de princípio (contra o inimigo) e argumento de circunstância (para si). A minha hipótese é a de que talvez possamos encontrar uma boa resposta, ou um bom começo de resposta, nas análises que Hannah Arendt, nas décadas de 1950 e 1960, e Ruy Fausto, em livro recente de 2017, fazem da gênese do totalitarismo de esquerda.

0 presente artigo retoma essas duas análises com o intuito de tentar compreender as raízes múltiplas desse ethos relativista a respeito da violência e dos direitos humanos, enquanto caraterística de uma certa esquerda. Ao traçar a gênese do totalitarismo soviético, tanto Arendt quanto Fausto seguem um caminho que volta do stalinismo para o leninismo, para o bolchevismo chegando ao jacobinismo, sem descuidarem do importante legado de Marx e também do menos evidente legado das filosofias modernas do progresso. Eu me proponho a reconstruir os seus argumentos procurando sublinhar as concordâncias de Fausto com Arendt que, apesar de serem muito significativas, não são explicitadas por ele. Ao buscar a gênese do totalitarismo de esquerda, o autor de $O$ ciclo do totalitarismo (2017) considera estar preenchendo uma lacuna deixada por Arendt, que teria reconstruído a gênese do nazismo, mas "tratado pouco da gênese do totalitarismo igualitarista" (Fausto, 2017, p.82). Nas páginas que seguem eu pretendo mostrar que embora Fausto, beneficiado pelos avanços da historiografia nos últimos sessenta anos, apresente um estudo mais detalhado do que o de Arendt - sobretudo a respeito da Revolução Russa -, ele segue o mesmo caminho analítico que ela havia percorrido nos anos 1950 e 1960 em busca da origem totalitarismo soviético. Faço isso menos para cobrar de Fausto que tivesse citado a fonte, mas para mostrar a complementariedade dos seus projetos críticos, mais potentes quando lidos conjuntamente. Para antecipar, parece que os dois nos dão boas razões para supor que a raiz mais antiga da cisão entre o argumento de princípio (para os outros) e o de circunstância (para si) se encontra no jacobinismo, que não viu contradição entre afirmar os direitos humanos e praticar o terror.

A primeira seção trata em linhas gerais da caracterização do totalitarismo de esquerda ou igualitário por Arendt e Fausto. A segunda e a terceira explicitam as concordâncias entre as duas análises a respeito do legado do jacobinismo para 
o bolchevismo, dos déficits democráticos de Marx e do leninismo, sem esquecer do problema que ambos detectam nas filosofias do progresso. A quarta seção explora a complementariedade entre a abordagem transcendente de Arendt e a abordagem imanente de Fausto a respeito da lei suprema do totalitarismo igualitarista e também as limitações da tese faustiana segundo a qual as revoluções comunistas implicam regressões que interrompem certa linha de progresso. Pretendo mostrar que essa tese, além de mal justificada, pode enredar o autor em problemas importantes. De outro lado, a ambiguidade positiva da explicação de Arendt - que comporta ruptura e continuidade e abdica de pensar em termos de progresso e regressão - consegue ressaltar a extrema violência da dominação totalitária nazista ou stalinista sem precisar amenizar as violências precedentes.

\section{Totalitarismo de esquerda, totalitarismo igualitário}

Publicado logo após o impeachment de Dilma Rousseff - processo político que Ruy Fausto qualificava como golpe - e pouco antes da eleição de Bolsonaro, 0 ciclo do totalitarismo (2017) tem, de acordo com o autor, o objetivo predominante de contribuir para o fortalecimento de uma "esquerda crítica e independente", capaz de reagir à atual ofensiva da extrema direita (Fausto, 2017, p. 64). Na esteira de $A$ esquerda difícil (2007), os textos reunidos em $O$ ciclo do totalitarismo sustentam a tese de que o fortalecimento da esquerda hoje requer um acerto de contas com o totalitarismo igualitarista, algo que exige, inevitavelmente, uma releitura da história do século XX, sobretudo a da Revolução de Outubro e Chinesa.

Algo bastante semelhante estava no horizonte de Arendt ao terminar a escrita de Origens do totalitarismo (1951), que lhe tomou 4 anos, entre 1945 e 1949: enfrentar a baixa densidade democrática da esquerda de seu tempo. E para ela, como também para Fausto tantos anos depois, isso requeria recontar a história da Revolução Russa sem apagar os vestígios dos antecedentes do que veio a se configurar como um governo totalitário, sob Stálin. Ciente de que havia um desequilíbrio importante em seu livro, que cuida mais das origens do nazismo do que do stalinismo, ela se propõe, então, a estudar mais a fundo os antecedentes do regime soviético começando justamente pela teoria hegemônica, a marxiana, e pelo bolchevismo. Há de se notar que "Ideologia e Terror", escrito em 1953 e acrescido às edições posteriores da obra, já explicita essa agenda de investigação, cujos resultados se encontram dispersos, por exemplo, no capítulo 3 de A condição humana (1958) e em Sobre a revolução (1963).

O primeiro passo, tanto para Arendt quanto para Fausto, é admitir que o regime comandado por Stálin era totalitário, algo que parte da esquerda contemporânea a ambos não admite, sendo essa recusa sintoma evidente da sua baixa densidade 
democrática ou da ilusão com a história (ou de ambos). Parece, portanto, que a expectativa é a de que recontar a história abriria uma janela para o fortalecimento de uma esquerda menos iludida e efetivamente democrática. Para Arendt, guardadas todas as devidas diferenças, se nazismo e stalinismo são regimes totalitários é porque compartilham algumas características que configuram uma dominação total da vida privada e pública baseada na ideologia e no terror, com absoluta centralização pelo governo burocrático e com a produção de cadáveres em massa. Fausto concorda com ela a respeito dos aspectos compartilhados e também sobre as enormes diferenças, e é justamente para marcar o comum na diferença que ele denomina um de totalitarismo igualitarista e outro de totalitarismo anti-igualitarista. 0 primeiro "deita suas raízes na história da esquerda e nas lutas populares pela emancipação e pelo socialismo", enquanto o segundo tem "uma gênese diferente, pois remete às experiências do lado contrário, isto é, às forças que se opõem aos movimentos populares” (Fausto, 2017, p. xix). Isso diz respeito à gênese de cada um ou pelo menos ao que cada um explicitamente pregava: a igualdade, num caso, e a desigualdade e a hierarquia, no outro. No entanto, sob modalidades diferentes, ambos acabaram se revelando antiigualitários, pois hiper repressivos e genocidas (idem, p. xx).

Fausto se baseia numa historiografia que, de acordo com ele, o permite contestar o mito de que a Revolução de 1917 foi em essência proletária e a chinesa, de 1949, camponesa. É absolutamente incontestável que houve grande mobilização popular, mas, infelizmente, isso não impediu que o poder passasse das mãos de uma elite para as de outra elite (Fausto, 2017, p.7). O caso russo é emblemático pois, logo depois de outubro, a definição do novo poder - que seria transitório e teria um caráter preparatório para a sociedade comunista - levou a "o fechamento dos jornais, a repressão policial, a liquidação progressiva dos sovietes e, not least, o fechamento brutal, no início de janeiro, da Assembleia Constituinte, livremente eleita" (idem, p. 17). Do mesmo modo, "não foram os camponeses chineses que decidiram onde desembocaria a revolução, foram os seus chefes, que não eram camponeses” (idem, p. 70).

Não interessa para os propósitos deste texto a avaliação que Ruy Fausto faz da Revolução Chinesa, mas a conclusão segundo qual "se os totalitarismos igualitaristas são patologias - e eles certamente o são - trata-se de patologias que exploram, em proveito próprio, lutas legítimas contra as patologias historicamente existentes" (idem, p. 8). Embora também não seja tema deste artigo, cumpre observar que, com isso, Ruy Fausto não pretende passar uma régua niveladora na história e tampouco negar as importantes diferenças entre leninismo e stalinismo. As diferenças são marcantes e talvez a principal, para ele, seja a de que Stálin respondeu à resistência dos camponeses com coletivização forçada e genocídio (idem, p. 16). Interessa menos aqui os detalhes dessa história e mais o fato de que a forma de governo instaurada 
foi da ditadura burocrática ao totalitarismo genocida - fato que certa esquerda teima em aceitar, num procedimento de negação da realidade que se aproxima daquele do negacionismo de direita (Idem, p. 37). Não se trata também de apagar as diferenças entre o caso russo e o chinês, mas de não mais esconder que a história do comunismo também na China "é uma sucessão de atos violentos e arbitrários cometidos contra gente inocente" (idem, p. 44). Para Fausto, uma sucessão de atos violentos "que não se pode justificar em nome do socialismo" (idem, ibidem).

Com isso, ele pretende recusar a leitura recorrente em certos círculos da esquerda de que as duas revoluções teriam significado um enorme progresso com relação às formas anteriores de dominação. Como falar de progresso num caso ou no outro se "a microestrutura política engoliu a infraestrutura social" (idem, p. 71)?. O processo não conduziu ao progresso porque não foi na direção do socialismo e tampouco, acrescenta Fausto, "na direção de um poder progressista” (p. 71). Tratase, nos dois casos, de "revoluções” - talvez não mereçam o nome - não emancipadoras, mas regressivas, que primeiro "conduziram a poderes totalitários e, afinal, a formas totalitário-capitalistas” (idem, p. xv). Ou seja, além de regredirem no plano da liberdade e do respeito ao indivíduo, terminaram no capitalismo e com alto grau de desigualdade (cf. idem, p. xxiv). Talvez o pior desdobramento possível - capitalismo neototalitário ou hiper autoritário - no qual se fecha um ciclo (idem, pp. 1 e 36):

Os poderes comunistas - o russo por exemplo - começam com formas que são autoritárias (pré-totalitárias, se se quiser) e depois evoluem (involuem) para formas totalitárias. Essas formas, por sua vez, envelhecem ou se rompem e dão origem a um pós-totalitarismo que tem alguma coisa em comum com o pré-totalitarismo (ou autoritarismo) de que partiu. Há aí uma espécie de ciclo (idem, p. 2).

Observo que, para afirmar o diagnóstico da regressão, Ruy Fausto precisa sustentar alguma ideia de progresso, pois para defender que as duas revoluções tenham implicado regressão histórica ele precisa se comprometer com a ideia de que elas interrompem uma linha de progresso histórico (cf. idem, p XV e XVI nota $x v)$. Voltarei a esse tema na seção final. Por ora, contento-me em destacar o seu argumento principal calcado numa historiografia que o ampara na tese, lançada cerca de 70 anos antes por Arendt, de que comunismo e nazismo têm histórias diferentes, mas compartilham certas características: "os campos, o genocídio, a violência contra as pessoas, uma ideologia e uma política expansionistas, etc.” (idem, p. xix).

Se o primeiro passo é defender que o totalitarismo não foi privilégio da extremadireita anti-igualitarista nazista, o segundo passo, de Arendt e também de Fausto, é buscar a gênese do totalitarismo de esquerda ou igualitarista. No texto que parafraseia o título do clássico arendtianao - "Sobre as origens do totalitarismo" - o que vai interessar a Fausto é a gênese do totalitarismo igualitarista, ou ainda, os seus antecedentes lógico-históricos (idem, p. 74). Antecedentes que o autor encontra, em 
primeiro lugar, na teoria hegemônica do movimento socialista, o marxismo, e, em seguida, retrocedendo um pouco mais na história e ampliando o escopo para além da teoria hegemônica: para a filosofia do século XVIII e da Revolução Francesa, "as quais serão o ponto de partida de uma gênese lógico-histórica que, passando pelo marxismo, nos conduzirá até o bolchevismo e ao stalinismo" (idem, p. 74). Observo que a gênese é lógica no sentido de que interessa mais ao autor investigar "como certas formas de pensamento e de ação poderiam ter servido como elementos para a constituição da ideologia e da prática totalitárias do que propriamente reconstituir linhas de causalidade histórica efetiva" (p. 74).

Essa proposta Fausto empresta de Arendt que, em Origens do totalitarismo, se propôs a uma investigação sobre o totalitarismo que não queria propriamente desvendar a sua cadeia causal, mas oferecer uma exposição histórica "dos elementos que se cristalizam no totalitarismo", ou seja, dos seus antecedentes e também da estrutura elementar da dominação tipicamente totalitária (Arendt, 2008, p. 419; Cf. Frateschi, 2021a). Como eu disse anteriormente, se é verdade, como observa Ruy Fausto, que em Origens ela não avançou na análise do caso soviético tanto quanto avançou a respeito no nazismo, em textos posteriores ela nos dá as pistas, mesmo que dispersas, de onde buscar os elementos que se cristalizam (em termos benjaminianos) no totalitarismo de esquerda: no jacobinismo e em Robespierre, em Marx e nos marxismos, na filosofia da história e no bolchevismo.

\section{Jacobinismo}

Em função dos limites deste artigo, eu não tenho a pretensão de uma análise exaustiva dos elementos da gênese do totalitarismo de esquerda e me limito a sublinhar alguns que dizem mais diretamente respeito à minha pergunta pela origem do ethos relativista da esquerda, que implica a disposição para a justificação da violência pelos motivos certos. A começar pelo jacobinismo, Fausto segue os passos de Arendt ao identifica-lo na gênese do totalitarismo igualitário soviético por intermédio do bolchevismo:

O bolchevismo sofreu um impacto importante - e consciente - da Revolução Francesa, em particular no jacobinismo. E, na medida em que o bolchevismo tem alguma coisa a ver com o totalitarismo stalinista, essa referência à Revolução Francesa e ao jacobinismo também nos ajuda, embora indiretamente, a entender o totalitarismo stalinista (Fausto, 2017, pp. 84-5).

Duas observações a partir daqui: 1) como Arendt, Fausto não supõe uma simples continuidade entre bolchevismo e stalinismo, mas defende que o bolchevismo está na gênese, inclusive intelectual, do totalitarismo (p. 82); 2) como Arendt também, Fausto não estabelece uma relação direta entre jacobinismo e stalinismo, obviamente, mas 
defende que indiretamente o jacobinismo está na gênese, intelectual inclusive, do stalinismo. A respeito do jacobinismo, é preciso sublinhar que a análise faustiana de 2017 ressalta dois pontos que também são centrais para Arendt em Sobre a revolução (1963): a exaltação da virtude cívica com um caráter iminentemente ético e a prática da violência (Fausto, 2017, p. 88). A violência fundada na virtude desemboca no terror, ou, nas palavras de Fausto, trata-se de uma "ética que funda a violência e justifica o terrorismo" (idem, p. 80). Arendt havia desvendado essa relação entre virtude e violência no jacobinismo na obra de 1963: ao transformar a compaixão na mais elevada virtude política, Robespierre introduz um elemento passional na política que abre as portas para a violência e a justifica (Cf. Arendt, 2011, pp. 124-127; Frateschi, 2021b, pp. 308-311). Para ambos, a chegada dos jacobinos ao poder muda os rumos da revolução que começou genuinamente popular em nome da liberdade e da igualdade. Na interpretação de Arendt, eles não estavam propriamente interessados na liberdade e, alegando compaixão com os despossuídos, pisotearam a justiça e desencadearam um turbilhão de violência ilimitada (cf. Arendt, 2011, p. 127 e Fausto, 2017 p. 89).

Mas como fica a contradição do terror com a própria ideia de "direitos do homem", central naquela Revolução? Fausto entende que as duas tendências acabam por se conciliar a partir do momento em que parece plenamente justificado que os direitos do homem valem para o bom cidadão e a "virtude-violência para todos os refratários, inimigos da República”, sendo que o papel da justificação ficou a cargo da virtude: para os virtuosos, os direitos do homem; para os viciosos, a violência (Fausto, 2017, p. 89). Novamente aqui, a concordância não explicitada com Arendt salta aos olhos, afinal a pergunta havia sido posta e respondida nos mesmos termos no livro de 1963: o ponto de inflexão da Revolução Francesa foi o momento em que os direitos do homem se transformaram nos direitos dos sans-culottes (Arendt, 2011, p. 94), algo justificado pelo "terror da virtude" de Robespierre (idem, p.117). Em suma, eram os jacobinos que definiam para quais homens (e mulheres) valiam os direitos do homem.

$\mathrm{Na}$ interpretação de Fausto, o que o jacobinismo legou ao bolchevismo e depois ao totalitarismo stalinista foi justamente o voluntarismo e a ditadura terrorista (cf. Fausto, 2017 p. 90). Nisso também Arendt o antecedeu, ao afirmar que os bolcheviques aprenderam com os jacobinos a "desempenhar qualquer papel que o grande drama da história lhes atribuísse" (Arendt, 2011, p. 91). Em outras palavras, os homens da Revolução Russa aprenderam com os da Francesa que a violência está plenamente justificada quando supostamente a favor da Revolução: “Em termos políticos, pode-se dizer que o mal da virtude de Robespierre consistia em não aceitar nenhum limite" (idem, p. 129). Foi assim que o poder do povo recém conquistado (embora não constituído) "se esfacelou num caos de violência” (idem, p. 131). Arendt 
e Fausto concordam que essa rendição à violência e a consequente destruição do anseio por liberdade e igualdade passou de mãos jacobinas para bolcheviques, não a favor, mas contra a Revolução. Concordam também que o Partido, nos dois casos, foi peça chave no aniquilamento daquilo que Arendt chamou de "novas instituições da liberdade" nascidas no primeiro momento das Revoluções, as Assembleias Populares, os Soviets, as Comunas (cf. Arendt, 2011, p. 101; Fausto, p. XX):

Não foi apenas na Revolução Francesa, e sim em todas as revoluções inspiradas em seu exemplo, que o interesse comum apareceu sob os traços do inimigo comum, e a teoria do terror, de Robespierre a Lênin e Stálin, pressupõe que o interesse do todo deve ser automaticamente - na verdade, permanentemente - hostil ao interesse particular do cidadão (Arendt, 2011, p. 116).

Com isso, Arendt, como Fausto posteriormente, queria explicitar que essas revoluções falharam tanto em instituir a liberdade, quanto a igualdade, pois a igualdade também se expressa em termos jurídicos e políticos: "os homens da revolução não estavam mais preocupados com a emancipação dos cidadãos nem com a igualdade no sentido de todos terem igual direito à sua personalidade jurídica, de serem protegidos por ela" (idem, p. 150). Embora o totalitarismo igualitário seja construído sobre a ideia de igualdade, ambos entendem que a igualdade se torna uma ideia limitada, problemática e perigosa ao perder o seu aspecto jurídico e político para coincidir com o que Fausto detecta como uma tendência a "igualizar o conjunto da sociedade" (Fausto, p. 86). Com isso, a igualdade se torna cumplice do despotismo (idem, p. 87) e inteiramente incompatível tanto com a participação política quanto com a liberdade, assim como inimiga de tudo o que diz respeito ao particular e ao individual. Para ambos, não se trata se escolher entre liberdade e igualdade em termos materiais, mas de buscar torná-las compatíveis, por mais utópico que isso pareça à esquerda ortodoxa revolucionária, à direita capitalista e aos liberais de todas as estirpes. Eles estão convencidos de que os projetos até então existentes que sacrificaram a liberdade em nome da igualdade ou vice versa não são uma alternativa aceitável e que, portanto, precisamos de outro. Voltarei a isso na conclusão.

Se, por um lado, o jacobinismo manteve como referência a Declaração Universal dos Direitos do Homem, por outro lado, em mãos jacobinas (e depois bolcheviques) esses direitos estão à mercê das circunstâncias, o que evidentemente contraria a expectativa universalista e normativa da ideia de direitos humanos. Trata-se, de acordo com Fausto, de um "antitrancendentalismo das circunstâncias" (idem, p. 106), que - eu acrescento - continua ainda hoje a atrapalhar os anseios de uma esquerda que quer poder voltar a pensar num projeto socialista democrático (daí a necessidade incontornável de desconstruir os mitos alimentados por uma histografia ufanista da Revolução Russa). No final dos anos 1940, Arendt já havia notado 
que a destruição da ideia de humanidade foi precursora do racismo da burguesia imperialista do século XIX e, portanto, da barbárie que os europeus cometeram em solo africano contra aqueles não considerados propriamente humanos, os negros. A mesma burguesia que em casa alimentava discursos liberais universalistas adotava, nas colônias, o que Fausto chama de “ “antitranscendentalismo' das circunstâncias”. Em África, os direitos humanos estavam suspensos pela excepcionalidade da situação. Embora as esquerdas, por unanimidade, considerem hipócrita e assassino o antitranscendentalismo de circunstância da burguesia imperialista europeia, nem toda esquerda considera hipócrita e assassino o antitranscendentalismo de circunstância jacobino e bolchevique.

\section{Marx, as filosofias do progresso e o bolchevismo}

A respeito de Marx, Fausto converge com Arendt no seguinte: a despeito da sua capacidade inegável para desvendar os mecanismos do sistema capitalista, o descompromisso de Marx com a democracia é um problema para a esquerda e deve ser levado em consideração quando se trata de avaliar as origens do totalitarismo igualitarista. De acordo com Fausto, Marx “não fez da democracia nem um ponto de chegada, nem um verdadeiro ponto de partida para a transformação socialista, isto é, comunista, das sociedades modernas" (Fausto, 2017, p. 76). O problema principal - que permanece como herança - é que o projeto socialista, ao se definir como anticapitalista, acabou definindo-se também como antidemocrático, afinal, o socialismo nasceria do fim do modo de produção capitalista e da sua forma política.

Para Ruy Fausto, é preciso repensar essa identificação entre capitalismo e democracia para sustentar uma posição de esquerda que seja a um só tempo anticapitalista e democrática. Fausto certamente avança em relação a Arendt nesse aspecto, pois se ela se contenta em sustentar que capitalismo e socialismo são gêmeos usando chapéus diferentes - razão pela qual um não é alternativa ao outro (Arendt, 1973, p. 184) - ele vai mais longe ao afirmar que, na medida em que "capitalismo e democracia se contradizem" (Fausto, 2017, p. 77), nós precisamos de um projeto socialista e democrático:

Enquanto houver capitalismo a democracia é necessariamente imperfeita. O que não impede que, a despeito de sua imperfeição - e em determinado sentido, por isso mesmo, já que a reivindicação da democracia é inseparável da exigência de aperfeiçoá-la -, ela seja um bom ponto de partida, talvez mesmo o ponto de apoio fundamental para qualquer projeto socialista (idem, ibidem).

Embora não se deva reduzir Marx ao Manifesto Comunista, evidentemente, a versão da revolução ali contida abre as portas para projetos anticapitalistas não emancipatórios, porque não democráticos e coniventes com a violência (idem, p. 
80). Para Fausto, como para Arendt (e Adorno, a quem Fausto se refere no lugar de Arendt), a violência é elemento decisivo no "deslizamento do projeto socialista em direção da sociedade totalitária” (idem, p. 80). E Marx tem algo a ver com isso, ainda que decididamente não possa ser responsabilizado pelo horror stalinista.

Antes de prosseguir, é fundamental ressaltar que Arendt e Fausto não pensam que Marx deva ser responsabilizado pelo uso que as lideranças políticas fizeram da sua obra (assim como Rousseau não pode ser responsabilizado pela maneira como Robespierre usou o Discurso sobre a Origem e o Fundamento da Desigualdade entre os Homens para justificar o terror). Sobretudo no que diz respeito ao uso da violência, Marx teria sido mais reticente e ambíguo do que boa parte dos marxistas, quase sempre mais dogmáticos que a fonte (cf. Fausto, 2017, p. 91; Arendt, 2011 p. 95). No entanto, há elementos da teoria marxiana que alimentaram os seus desdobramentos e que devem ser levados em consideração na construção de uma "narrativa da gênese do totalitarismo", algo que tanto a storyteller Hannah Arendt quanto Ruy Fausto se propõem a fazer. Como vimos acima, o primeiro deles e o mais evidente é o descompromisso de Marx com a democracia (e com a liberdade), sublinhado por Fausto na obra de 2017; uma avaliação semelhante à de Arendt, que, desde pelo menos o início dos anos 1950, vinha ressaltando que o projeto marxiano implica, no limite, a destruição da própria política: a harmonia comunista seria de tal ordem que não precisaríamos de governo, leis, divisão de poderes e todas essas minúcias dispensáveis das democracias burguesas (cf. Arendt, 2010, cap. 3).

Se Arendt havia insistido nos limites políticos do materialismo marxiano (principalmente pela má compreensão dos conflitos de natureza não econômica), Fausto insiste que o tipo de imanentismo que o materialismo introduz está na base do "antitranscendentalismo" do próprio Marx e dos seus seguidores (Fausto, 2017, p. 95). Não que este seja o único aspecto a ser sublinhado da crítica da economia política, evidentemente. Para Fausto, contudo, a parte potente e profunda da crítica - a que mostra como se dá a “interversão das relações de apropriação" e como, no capitalismo, a igualdade se interverte no seu contrário (idem, pp. 96-7) - ficou à sombra, em grande parte por culpa da tradição marxista:

$\mathrm{E}$, assim - e é isso o que eu quero ressaltar aqui -, da crítica da economia política ficou apenas um aspecto, a saber, o de uma crítica que, sem dúvida reconstrói o discurso dos economistas; mas que descamba, em última análise, numa visada redutora da história (um antitranscendentalismo - radical), pois se trata de uma visada em que outros valores estão ausentes, tanto pelo lado do sujeito como também no plano do objeto (...). Foi assim que de uma crítica de uma extraordinária riqueza, que tinha, entre outros méritos, o de não ser nem moralista, nem amoralista, resultou uma concepção que se poderia chamar de imanentista da história (....), radicalmente antitranscendentalismo (Fausto, 2017, p. 97).

Ainda que Arendt não formule o problema nos mesmos termos que Fausto - o 
problema, para ela, não é propriamente o imanentismo antitranscendentalista, mas a definição da história como a história da luta de classes que vem a justificar o uso da violência para a realização do seu fim (algo com feição mais transcendente do que imanente) -, ambos concordam que a raiz dos reducionismos de Marx deve ser buscada na sua adesão às filosofias do progresso e no tipo de determinismo que ele acaba por abraçar. Para Arendt e Fausto, este é um aspecto do pensamento de Marx "essencial para pensar o que vem depois" (Fausto, 2017, p. 92), afinal, "se o curso do progresso é em si mesmo aberto, ele tem um estágio quase final na figura de uma sociedade transparente" (idem, p. 93). É esse fim, esse telos garantido pelas leis da história, que permitirá, aliás, o fim do Estado, prescindível quando se alcançar o progresso “do homem geral” ou, nas palavras de Arendt, o "Paraíso na Terra":

O lugar de Marx na história da liberdade humana sempre será ambíguo. É verdade que, na obra de juventude, ele falou da questão social em termos políticos e interpretou a condição da pobreza segundo as categorias da opressão e da exploração; mas também foi Marx quem redefiniu, em quase todos os seus textos posteriores ao Manifesto Comunista, o impulso autenticamente revolucionário de sua juventude em termos econômicos. Se de início ele vira a violência e a opressão do homem pelo homem onde outros haviam enxergado alguma necessidade inerente à condição humana, mais tarde passou a ver as leis férreas da necessidade histórica espreitando por trás de toda violência, de toda transgressão e violação (Arendt, 2011, p. 98).

É importante notar que Fausto é mais generoso do que Arendt ao perceber que, ao introduzir certas determinações gerais da história, Marx o fez com grano salis (Fausto, 2017, p. 98). Mais categórica, Arendt vê ali continuidade com a filosofia da história hegeliana, de tal modo que a aparente inversão de Hegel acaba colocando Hegel novamente “de cabeça pra cima” (Arendt, 1992, p. 63; cf. Frateschi, 2021c, pp. 242-257). De qualquer modo, ambos estão de acordo sobre a raiz filosófica do problema: o esquema histórico do progresso facilita a compreensão de que a história opera por leis tal qual o mundo natural (cf. Arendt, 2004, p. 513 e Fausto, 2017, p. 105). No limite, o cientificismo fantasioso de Marx - radicado nas filosofias do progresso - é a origem dos seus outros reducionismos e está na gênese do bolchevismo. Em “Ideologia e Terror” (1953), Arendt antecipa Fausto, ao notar que

Sob a crença bolchevique numa luta de classes como expressão da lei da história está a noção de Marx da sociedade como produto de um gigantesco movimento histórico que se dirige, segundo a sua própria lei de dinâmica, para o fim dos tempos históricos, quando então se extinguirá a si mesmo (Arendt, 2004, p. 515).

Interessa a ambos que a violência revolucionária é a realização dessa lei, sendo o seu principal objetivo tornar possível à história "propagar-se livremente por toda a humanidade sem o estrovo de qualquer ação humana espontânea” (idem, p. 517). Como diz Fausto: "O legado do jacobinismo vai encontrar uma filosofia da história que acolhe os determinismos: e agora as linhas do determinismo e os 
esquemas da história se cristalizam propriamente em 'leis'” (Fausto, 2017, p. 105). Para ele, a mistura de jacobinismo com progressismo está na matriz original do bolchevismo, uma combinação “literalmente explosiva” (idem, ibidem). É verdade que o voluntarismo jacobino se transfigura quando entra em contato "com a versão leninista da ideia marxista de história", mas o ponto é que ele se radicaliza diante de uma história determinada "por leis que se supõem análogas às do mundo natural" (idem, ibidem). Para resumir, "A virtude jacobina se transforma, no bolchevismo, em crença nas leis da história” (idem, p. 104).

Embora não caiba aqui uma análise mais demorada do leninismo, cumpre notar que se Fausto vai mais longe do que Arendt baseado numa historiografia mais desenvolvida do que aquela na qual ela se baseara, ainda assim ele está de acordo com ela sobre o que parece ser o principal: tanto o bolchevismo quanto o leninismo são como que antecedentes do totalitarismo de esquerda, posto em prática efetivamente sob o mando de Stálin. Fausto os considera "pré-totalitários" (idem, p. 101) por ter consciência de que alguns aspectos principais do modo de organização e de governo totalitários não surgiram do dia para a noite. Lênin e o leninismo aprenderam com o Jacobinismo "a ausência de escrúpulos da concepção de violência, o que daria mais tarde no uso justificado do Terror" e um modelo centralizado de organização (idem, p.102), levados posteriormente por Stálin às últimas consequências com o genocídio. Sobre Lenin, Arendt tem uma avaliação semelhante, embora tenha afinidades explicitas com o que ela considera ser o projeto original leninista contido no lema "Eletrificação + Soviets”: “eletrificação como solução para o problema social da Rússia e o sistema de soviets como novo corpo político, que surgira durante a revolução fora de qualquer organização partidária” (Arendt, 2011, p. 100). No entanto, Arendt lamenta que isso não durou muito, pois logo Lenin abriu mãos tanto de um desenvolvimento econômico racional (e não ideológico) do país quanto dos soviets, aceitando que o Partido se tornasse a força motriz de ambos. Nesse sentido, ainda que não caracterize o governo de Lenin como "pré-totalitário", ela antecipa Fausto ao afirmar que ele "estabeleceu o precedente para o desenvolvimento posterior em que o partido e a máquina do partido se tornaram literalmente onipotentes" (idem, p. 100):

Lenin foi o último herdeiro da Revolução Francesa; ele não tinha nenhum conceito teórico de liberdade, mas, posto diante da realidade concreta, entendeu o que estava em jogo e, quando sacrificou as novas instituições da liberdade, os soviets, ao partido que julgou que libertaria os pobres, sua motivação e seu raciocínio ainda estavam de acordo com os trágicos fracassos da tradição revolucionária francesa (idem, p. 101).

Não à toa, Fausto e Arendt - tão afinados a respeito do desmantelamento das instituições democráticas revolucionárias pela elite partidária jacobina ou bolchevique - encontram em Rosa Luxemburgo as qualidades de uma posição a um só tempo de esquerda e democrática, mas esse é assunto para outro texto. 


\section{Antitranscendência, transcendência e a volta faustiana da filosofia da história}

$\mathrm{Na}$ busca de refletir sobre a gênese do relativismo de esquerda a respeito da violência e dos direitos humanos, nas páginas anteriores eu procurei trazer à tona a herança arendtiana da análise faustiana a respeito dos antecedentes do totalitarismo igualitarista. Em geral afinado com Arendt, num aspecto Fausto parece enveredar por um caminho diferente. Como vimos, ele insiste que há no marxismo uma tendência imanentista ou antitranscendental "de liquidar toda instância transcendental de origem jurídica (direito natural ou direito do homem) ou moral (imperativos éticos)" (Fausto, 2017, p. 114). No fundamental, até aqui, ele segue Arendt, para quem o marxismo sustenta uma relação bastante problemática com o direito (enquanto mera superestrutura) e com o governo constitucional, algo que se radicaliza nos governos totalitários de esquerda a ponto de o "lugar das leis positivas ser tomado pelo terror total" (Arendt, 2004, p. 516). Acontece que, para Arendt, o terror se destina a "converter em realidade a lei do movimento da história" (idem, ibidem). Nota-se, assim, que onde Arendt vê uma instância de certa maneira transcendente (que se pretende como tal) - isto é, a lei suprema da História enquanto lei do movimento -, Fausto vê uma tendência antitranscendente - que liquida, pela sua radical imanência, todo dever ser, toda norma jurídica ou moral.

Contudo, as duas abordagens, ao invés de se contradizerem, são complementares. Mais do que isso, na minha interpretação, as duas abordagens, aparentemente excludentes, nos proporcionam uma compreensão filosófica ainda mais rica da complexidade do totalitarismo (sobretudo do soviético) cuja gênese proporciona os elementos tanto de transcendência quanto de imanência dos quais se valeu para assumir a forma totalitária. A complementariedade é percebida pelo próprio Ruy Fausto:

As duas representações não se excluem e, apesar da aparência em contrário, na realidade, se complementam. A lei suprema do totalitarismo igualitarista é imanente, no sentido de que ela liquida toda instância ética ou jurídica transcendente. Ela tem entretanto algo como uma origem transcendente, enquanto é uma lei absoluta que se impõe à história, e que passa por cima das leis positivas (Fausto, 2017, p. 115).

Semelhantes e complementares, as abordagens de Fausto e Arendt sobre a gênese do totalitarismo igualitário deixam entrever, contudo, uma diferença filosófica que talvez não seja marginal. Como foi dito na primeira seção deste texto, para sustentar a tese de que as revoluções russa e chinesa implicaram regressão histórica, Fausto precisa se comprometer com a ideia de que ambas interrompem uma linha de progresso histórico. São regressões na medida em que conduziram a poderes totalitários e, finalmente, "a formas sociais totalitário-capitalistas" (idem, p. xv), e na medida em que promoveram uma interrupção, "uma inversão na linha 
do progresso, se é válido dizer que até aí, apesar de tudo, o mundo dos séculos XVIII e XIX teria seguido certa linha de progresso" (idem, ibidem). Com isso, Fausto deixa entrar em seu argumento uma certa filosofia da história que não se livrou completamente da ideia moderna do progresso e que, por isso mesmo, o enreda numa teia de dificuldades importantes.

A mais evidente dificuldade na qual Fausto se vê enredado está relacionada à hipótese de que os séculos anteriores, mais precisamente os séculos XVIII e XIX, teriam seguido "certa linha de progresso", que foi interrompida. Por não se dar ao trabalho de argumentar e oferecer os dados históricos e empíricos que sustentariam a tese de que houve "certa linha de progresso", Fausto nos deixa com uma tese impressionista e imprecisa, pois mal fundamentada. Há um inegável desequilíbrio entre a análise historicamente embasada do totalitarismo igualitarista do século XX e a suposição, que dispensa provas históricas, de que os séculos anteriores seguiam numa rota ascendente, mesmo que apenas no plano da liberdade e do respeito pelo indivíduo.

Ele mesmo parece estar ciente, nesse momento do argumento, de que dá um passo para um “terreno instável”, ao menos em termos metodológicos e no nível da fundamentação. No entanto, isso não é suficiente para fazê-lo questionar o conteúdo da sua tese, ou seja, ele o mantém, mesmo assumindo que pisa em terreno pantanoso do ponto de vista da justificação:

Por que falar em regressão? Há regressão porque fenômenos como genocídio, negação brutal do indivíduo, extermínio e ausência total de liberdade - para ficar em alguns traços - são evidentemente regressivos. Mas esse "evidentemente" está suficientemente justificado? O que estou supondo é que liberdade, autonomia e respeito à vida definem, em parte pelo menos, o progresso (Fausto, 2017, p. XV).

Esse argumento não leva em consideração que os séculos XVIII e XIX são também marcados pelo genocídio, pela negação brutal do indivíduo, pelo extermínio e pela ausência de liberdade. Para sustentar a sua própria filosofia da história, Ruy Fausto precisa fazer um estranho ajuste na história e omitir a realidade da maior parte do mundo nos séculos nos quais ele detecta progresso, assolada justamente pelos fenômenos que ele próprio identifica como "regressivos". O diagnóstico do progresso suprime a realidade do sul do mundo e das colônias, a economia baseada na escravização dos negros, o extermínio dos povos indígenas, o imperialismo genocida do século XIX, a corrida para África. Suprime ainda a própria realidade do povo russo antes da revolução. Ou Fausto também está disposto a assumir que entre os séculos XVIII e XIX a Rússia czarista seguiu “certa linha de progresso”? Progresso para quem? Hannah Arendt não cai na cilada da filosofia da história, preferindo caracterizar os totalitarismos não propriamente como regressões, mas como rupturas que introduzem formas de governo inéditas, nunca antes vistas, que desafiam as nossas 
categorias consolidadas de compreensão. A vantagem com relação a Ruy Fausto é a recusa de se comprometer com a ideia de progresso, pressuposto da tese de que os totalitarismos implicariam regressões. Mais sutil do que Fausto, para sublinhar a absoluta e medonha novidade dos totalitarismos com relação a todas as formas precedentes de dominação Arendt não precisa chegar ao ponto de afirmar que essa forma de dominação interrompe uma linha de progresso. Diferente disso, o que ela procura fazer em Origens do totalitarismo - como sabemos com mais empenho em analisar o nazismo do que o stalinismo - é traçar os antecedentes dessas formas inéditas, pois, embora inéditas, elas têm um vínculo com o passado, não brotaram do nada e foram precedidas por eventos históricos que as tornaram possíveis. Ao se comprometer com essa busca, mais informada pela história do que por uma filosofia da história do progresso, Arendt vê alguma continuidade histórica entre o Imperialismo do século XIX e o nazismo, na medida em que o Imperialismo deixa um legado para a dominação totalitária: o racismo e a prática de extermínio como política de Estado. Deste modo, na narrativa histórica arendtiana constam aqueles elementos omitidos pela tese faustiana da regressão: o racismo, o assassinato em massa dos povos africanos pelos europeus, a colonização sangrenta da Índia, a mentalidade assassina da burguesia imperialista, etc.

Mais complexa do que a tese faustiana, a ambiguidade positiva da explicação de Arendt - que comporta ruptura e continuidade - consegue ressaltar a extrema violência da dominação totalitária nazista ou stalinista sem precisar amenizar as violências precedentes. Arendt talvez dissesse que Fausto não completou o serviço: foi feliz na crítica da ilusão marxista do progresso, mas com o risco de substituir uma ilusão por outra, sustentando uma visão fantasiosa da história segundo a qual as coisas caminhavam bem nos termos na liberdade e da igualdade até que as revoluções comunistas interromperam o curso da história. Se não é o que pretendia Fausto, teria sido melhor fazer como Arendt, livrando-se de uma vez por todas de uma filosofia da história que ainda opera com o par conceitual progresso/regresso, até por ser esta uma postura filosófica mais condizente com o diagnóstico de que nem o capitalismo nem o comunismo ofereceram respostas aceitáveis de um ponto de vista que não aceita abdicar da igualdade em nome da liberdade ou da liberdade em nome da igualdade (que é o ponto de vista tanto dele quanto da Arendt). Dizer que as revoluções comunistas interromperam uma linha de progresso sugere que o capitalismo implicou progresso, o que não parece ser a intensão de Ruy Fausto.

\section{Considerações finais}

O melhor da crítica de Fausto, quando não se deixa levar pela filosofia da história, é trazer à tona as insuficiências tanto do capitalismo quanto do comunismo 
em nome de um novo projeto, de uma nova resposta de esquerda, que saiba ser anticapitalista sem ser antidemocrática. Tanto para ele quanto para Arendt o comunismo não se ofereceu como resposta ao capitalismo por ter se realizado como ditadura ou totalitarismo, daí a necessidade de um outro projeto. 0 problema é que a construção prática e teórica desse novo projeto requer da esquerda um enfretamento com as suas próprias ilusões e com a sua própria história de justificação da violência e supressão dos direitos civis, políticos e humanos. Ao reconstruir as análises de Arendt e Fausto da gênese do totalitarismo de esquerda, notamos que, para ambos, a raiz mais antiga da cisão do que eu denominei de argumento de princípio (contra o inimigo) e de circunstância (para si) se encontra no jacobinismo, que não viu contradição entre afirmar os direitos humanos e praticar o terror, sem jamais deixar de ser implacavelmente crítico da violência cometida pelo antigo regime. Com esse legado, o bolchevismo, o leninismo e, finalmente, o stalinismo, levaram à derrota da Revolução Russa. Contudo, há de se observar, para terminar, que o fato de censurarem a ditadura de partido único de Lenin e o totalitarismo de Stálin não os leva, como costuma levar os liberais em geral, a uma adesão acrítica à democracia - formal e restritiva - das sociedades capitalistas do pós-guerra. Nas palavras de Arendt, se é verdade que "a distância entre a tirania e o governo constitucional é tão grande ou talvez ainda maior do que a distância entre o governo limitado e a liberdade", isso não deve os induzir ao erro de "confundir direitos civis com liberdade política, nem de pensar que essas preliminares do governo civilizado [constitucional] equivalem à substância de uma república livre” (Arendt, p. 278). Ao se referir ao bipartidarismo estadunidense, Arendt é categórica: “o máximo que conseguiu foi um certo controle dos governados sobre os seus governantes, mas não permitiu de maneira alguma que o cidadão se tornasse um 'participante' dos assuntos públicos” (idem, p. 336). Ou seja, admitir que houve totalitarismo de esquerda não implica negar que as democracias capitalistas tenham se tornado oligarquias, formas de governo "em que poucos governam no interesse, pelo menos supostamente, da maioria” (p. 337). Daí a necessidade de um projeto de esquerda que supere as limitações do comunismo real, do capitalismo e da democracia capitalista.

As análises de Arendt e Fausto sobre a gênese e a estrutura do totalitarismo de esquerda valem ainda por apontar para algo que a esquerda precisa se dispor a fazer para se contrapor à extrema direita que hoje a combate ferozmente no mundo todo. A começar pelo próprio compromisso com a verdade, afinal a extrema direita negacionista declara guerra à história e, no Brasil, nega que o golpe de 1964 (batizado de "revolução") instaurou uma ditadura, assim como nega a existência do holocausto. É o momento de considerar que talvez a esquerda não se capacite para questionar o negacionismo da direita se também é negacionista naquilo que a convém, se continua mistificando governos genocidas e justificando a violência "anti- 
imperialista" (Fausto, 2017, p. 63). É o momento ainda de considerar que talvez a esquerda não se capacite para questionar a violência e a crescente violação dos direitos humanos pelos atuais governos de direita e extrema direita nas sociedades capitalistas neoliberais se não se assumir inexoravelmente democrática, a favor da igualdade $e$ da liberdade.

\section{Referências}

Arendt, H. (1973). Crises da república. Trad. de José Volkmann. São Paulo: Perspectiva. Arendt, H. (1992). “A tradição e a época moderna”. In Entre o passado e o futuro. 3. ed. Trad. de Mauro A. Barbosa. São Paulo: Perspectiva, pp. 43-68.

Arendt, H. (2004). Origens do totalitarismo. Trad. de Roberto Raposo. São Paulo: Companhia das Letras.

Arendt, G. (2008). Compreender: Formação, exílio e totalitarismo. Kohn, J. (org.); trad. de Denise Bottmann. São Paulo: Companhia das Letras.

Arendt, H. (2011). Sobre a revolução. Trad. de Denise Bottmann. São Paulo: Companhia das Letras.

Arendt, H. (2014). A condição humana. Trad. de Roberto Raposo. São Paulo: Forense Universitária.

Fausto, R. (2007). A esquerda difícil: Em torno do paradigma e do destino das revoluções do século XX e alguns outros temas. São Paulo: Perspectiva.

Fausto, R. (2017). O ciclo do totalitarismo. São Paulo: Perspectiva.

Frateschi, Y. (2021a). "Hannah Arendt: sobre Hobbes, o imperialismo e o totalitarismo". In Liberdade, cidadania e ethos democrático: estudos antihobbesianos. São Paulo: Editora Alameda.

Frateschi, Y. (2021b). “Liberdade e cultura democrática em Hannah Arendt". In Liberdade, cidadania e ethos democrático: estudos antihobbesianos. São Paulo: Editora Alameda.

Frateschi, Y. (2021c). “Juízo e opinião em Hannah Arendt”. In Liberdade, cidadania e ethos democrático: estudos antihobbesianos. São Paulo: Editora Alameda. 